\title{
POSITIVE OUTCOMES OF OFFICE ERGONOMICS IN TERMS OF HIGHER PRODUCTIVITY
}

\author{
UDC: 005.961:005.336.1]:338.312 \\ Review Scientific Paper \\ Edit TEREK $^{1}$, Zvonko SAJFERT ${ }^{2}$, Katarina ZORIĆ ${ }^{2}$, Sladjana ISAKOV ${ }^{2}$ \\ ${ }^{1}$ University of Novi Sad, Technical faculty "Mihajlo Pupin” in Zrenjanin, 23000 Zrenjanin, Đure Đakovića bb, \\ Republic of Serbia \\ E-mail: terekedita@gmail.com \\ ${ }^{2}$ University of Novi Sad, Technical faculty "Mihajlo Pupin" in Zrenjanin, 23000 Zrenjanin, Đure Đakovića bb, \\ Republic of Serbia
}

Paper received: 12.03.2014.; Paper accepted: 21.05.2014.

\begin{abstract}
One of the sciences which considers to human health, human performance and body activities is Ergonomics. Ergonomics is one of the modern sciences, drawing as much from the field as from the laboratory, and including elements of art and craft as well. Before designing the workplace it is necessary to determine its requirements, i.e., which it is intended for, what are the characteristics of the existing work equipment and the additional tools needed. However, there are some standards and with their application people will prevent the occurrence of modern office diseases. This paper is focused on the positive aspects of ergonomics in improvement of the working environment.
\end{abstract}

Key words: office ergonomics, productivity, computer usage, visual environment, working environment.

\section{INTRODUCTION}

According to (Phesant, 2003) ergonomics was derived from two words „ergo“ which means work and „normia“ which means laws. Chapanis (1996) defines ergonomics as a multi-disciplinary field, with psychology (primarily experimental psychology), anthropometry (the applied branch of anthropology), applied physiology, environmental medicine, engineering, statistics, operations research and industrial design all contributing. Ergonomics is a branch of science that is concerned with the achievement of optimal relationship between workers and their work environment (Tayyari and Smith, 1997). The main objective of ergonomics is fitting the task to the man and not vice versa. Ergonomics or Human factors engineering as a multidisciplinary science are related to several kinds of science such as medical and health science, management, engineering disciplines, art and design, psychology. So, some different activities and performances are covered by ergonomics (Sadeghi et al., 2011).
The use of modern technology has brought great benefits, but some dangers as well. With the development of society an awareness of the dangers which the person is exposed to in the workplace, working and living environment also develops. These dangers range from mechanical, chemical, biological, ergonomic, electric, to psychological and physical. Probably there is no company that does not use computers in their business. The use of computers has brought undoubted benefits to all areas of life, especially at work. In addition, every employer is required to meet certain requirements for the application of preventive measures to ensure the safe operation at using the computer. In Serbia, at the end of 2009 a rulebook on preventive measures for safe and healthy work, when using the work equipment/screen was adopted (Official Gazette of the Republic of Serbia nr. 106/09, 2009). Beside employers who should apply the provisions of these regulations, employees should also be familiar with its contents and because of their health and safety they should adhere to the recommended measures. The office ergonomics training was designed following instructional 
systems design principles and based on adult learning theories (Robertson et al., 2009).

\section{CONDITIONS REQUIRED TO SECURE USING OF COMPUTERS}

Administrative positions are not usually considered as workplaces with significant risk. However, there are several prerequisites that must be met at each workplace and work environment. This is primarily related to the working environment and infrastructure. As the number of sitting work-tasks increases, proper adjustment of the seated workplace becomes increasingly important.

The computer should be placed in the work area with a favorable microclimate conditions (light, humidity, temperature and noise). In addition, access to a computer should be suitable and sufficiently spacious in the area where it is located. In this way, a computer allows the user freedom of movement and changing positions during labor.

The surface of the table where the computer is located should be of sufficient size so as to enable putting also other temporary or permanent facilities or required documents. In addition, it is preferred that there is a source of natural light, as well as suitable artificial light, it should be taken care about the position of the screen taking into account the light source, in order to prevent reflections. Windows should be provided with adequate protection that could reduce or increase the amount of natural light.

Chair design has the potential to influence viewing angle and distance. Recommended optimum viewing ranges vary from 50 to $100 \mathrm{~cm}$ (Taptagaporn et al., 1995; Jaschinski et al., 1998). It is suggested that the optimum distance is linked to the user's vision system and is best chosen by the worker (Jainta and Jaschinski, 2002). According to (Burgess-Limerick et al., 2000) viewing angle is achieved through a mixture of changing neck posture, trunk inclination and moving the eyes within the head. As such, an optimum angle is a balance between musculoskeletal concerns and eye comfort and typically is found to be slightly below the horizontal (Sommerich et al., 2001). A highly adjustable office chair coupled with office ergonomics training can address all of these factors affecting visual symptoms of users. The highly adjustable chair used in the intervention was designed to allow the user to minimize changes in head location during dynamic use by having the seat slide forward when leaning backward in the chair (Reinicke et al., 1986). This supports the user's maintaining his or her hands on the keyboard (Bush and Hubbard, 1999). The ease of supported back movement may allow the worker to individually adjust their viewing distance without having to move the monitor. It may also allow comfortably minimizing glare by improving the opportunity to readjust eye location with respect to the monitor. Improved height adjustability with the chair may also allow the user to find a comfortable viewing angle without changing monitor height. Fig. 1 displays the a priori theory of change guiding the research (Amick et al., 2003). The office ergonomics training was expected to increase knowledge and with the new highly adjustable chair (Fig. 2) postural risks are reduced and healthy computing behavior encouraged. (Amick et al., 2012).

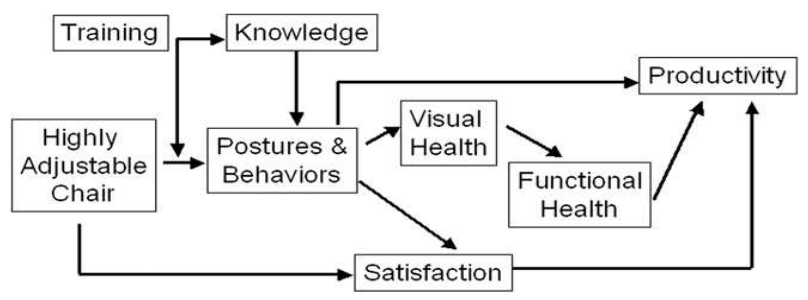

Figure 1:Theory of change (Amick et al., 2012)

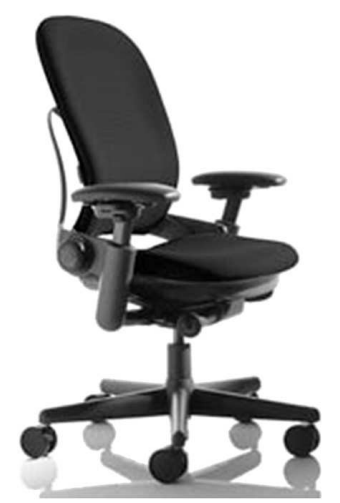

Figure 2: Highly adjustable chair (Amick et al., 2012)

\section{VISUAL ERGONOMICS}

In some countries the number of people who use a computer at work climbs to more than $70 \%$ of the population, and nearly three quarters of them have problems with vision or eyes, mostly people over forty years of age. These issues are unified under the name of Computer Vision Syndrome (CVS) or "Computer Vision Syndrome". This syndrome consists of the following symptoms: fatigue, dry eyes, the feeling of burning eyes, sensitivity to strong light, blurred vision, headaches that cause dizziness and nausea as well as pain in the 
shoulders, neck and back. (Rulebook on preventive).

When vision is unsatisfactory, the body adapts to a posture aimed at improving it: "The eyes lead the body" (Anshel, 2005). The visual environment can change the mood of people, which can alter their behavior (Boyce, 2004). There are many different mechanisms involved in enhancing human performance by light, visual comfort, visual ambience, interpersonal relationships, and the change process (Juslén and Tenner, 2005). According to Boyce et al (2006) there are correlations between productivity and eye fatigue, and direct/ indirect lighting systems can enhance motivation and attention during the working day. Based on present knowledge, the work related ocular/visual disorders and disturbances reported in the literature have a multifactorial origin, namely, task characteristics, environmental conditions and individual characteristics (Piccoli, 2003).

Another visual ergonomics factor is the size of the printed text. Words written in lower case with an initial capital letter are easier to detect than words with only lower case or capital letters (Phillips, 1979). Texts set in serif typeface, such as Times New Roman, are recommended because they are easy to read (MacLeod, 2000). In a study by Horgen et al. (2007), the size of the text also affects productivity in computer work. The recommended minimum size is 12 points, which represents a visual acuity of 20/60, depending on the screen size.

\section{GOOD ERGONOMICS IS GOOD ECONOMICS}

According to Hendrick (2001) good ergonomics is good economics. Among a great diversity of positive effects of applying ergonomics, productivity and comfort are described in the literature. Positive effects of ergonomics are described in office work (Brauer et al., 2003; Hedge and Sakr, 2005).

According to (Amick et al., 2012) their research, coupled with Norwegian studies, suggests that both medical and office ergonomic interventions may improve visual health and potentially productivity. Further intervention research is needed to support these findings and provide the knowledge base for occupational safety and health practice.
In these studies (Brauer et al., 2003; Hedge and Sakr, 2005; de Looze et al., 2005; Rosecrance et al., 2005; Vink, 2005), it was possible to increase sales or productivity in combination with better well-being or comfort. This should be of interest to more ergonomists and the society. However, it is not easy to achieve these goals; it is important to define the factors of importance to achieve these successes more often. However, there is no universally agreed list of success factors.

In a study by Vink and Kompier (1997), a step-bystep approach to better work was applied, aimed at reducing mental and physical workload in office work. This approach was evaluated. The approach consisted of six steps, including the definition of the problem, selection of solutions and testing the solutions. After every step the workers are proposed how to continue and a steering group led by the management decided whether to accept the proposal. The workers identified the problems, developed ideas for improvement, tested improvements and chose them. Height-adjustable furniture was bought and organizational measures were taken to reduce the mental load. Examples of organizational measures were better appointments on earlier delivering information and distinction between work that has to be done before a certain date and work that can be postponed (prioritizing). Finally, some workers were trained to encourage the continuation of adjustments and train new employees on the ergonomically ideal workstation and work organization. As a result, most workplaces were adjusted and more than half of the subjects took organizational measures (Table 1). The approach took about 1 year to achieve better working conditions but was considered worthwhile, despite the fact that it was time consuming. Physical discomfort was reduced, especially in the neck and shoulder region, and productivity was improved, especially by a more transparent and efficient process.

\section{CONCLUSION}

Analysis of previous experience suggests that in the future development of ergonomics will move in the direction of adjustment socioeconomic compelling need which will cause further diversification. The wide use of information technology inserts the complex demands in the field of ergonomics research and practical application of ergonomics. 
Table 1: Percentage of employees having adjusted the work $(n=29)$, and percentage of those employees with back or neck complaints $(n=18)$ that report a positive effect of these adjustments on back and neck complaints (Vink and Kompier, 1997)

\begin{tabular}{|l|c|c|}
\hline & $\begin{array}{c}\text { Workers with } \\
\text { adjustments (\%) }\end{array}$ & $\begin{array}{c}\text { Workers reporting } \\
\text { positive effects on } \\
\text { neck/back (\%) }\end{array}$ \\
\hline Chair height adjustment & 73 & 67 \\
\hline Table height adjustment & 83 & 67 \\
\hline VDU screen position adjustment & 69 & 50 \\
\hline Keyboard position adjustment & 34 & 11 \\
\hline Addition of document holder & 14 & 17 \\
\hline Addition of inclined desk & 31 & 11 \\
\hline Agreements with other departments & 48 & 28 \\
\hline Addition of telephone days & 24 & 11 \\
\hline A new planning of activities & 59 & 28 \\
\hline More varying work tasks & 48 & 28 \\
\hline Setting priorities in work & 100 & 28 \\
\hline
\end{tabular}

Using a computer at work, which is now widely spread cannot cause some serious injuries. However, the safe handling of the computer is important because of the potential musculoskeletal damage due to long working hours in an ergonomic unfavorable position, and vision damage because of the use of defective monitors.

As long-term working on the computer is not medically safe, responsible behavior, and by using ergonomic equipment and tools, users may preserve their own health. The ergonomically designed work place in the modern world, as well as developing new devices, guidelines, and standards for supplements that will improve the health of computer users is a priority.

It was the aim of this paper to convince ergonomists to focus more on the positive side of ergonomics. The positive aspects of increasing comfort and productivity are highlighted.

\section{REFERENCES}

Amick, I. B. C., Menéndeza, C. C., Bazzanid, L., Robertsone, M., DeRangof, K., Rooneyd, T., \& Moore, A. (2012). A field intervention examining the impact of an office ergonomics training and a highly adjustable chair on visual symptoms in a public sector organization. Applied Ergonomics, 43(4), 625-631.

Amick III, B. C., Roberston, M. M., \& DeRango, K. (2003). Effect of office ergonomics intervention on reducing musculoskeletal symptoms. Spine, 28(4), 2706-2711.

Anshel, J. (2005). Visual Ergonomics Handbook. Boca Raton, Florida: Taylor \& Francis Group.

Boyce, P. R. (2004). Lighting research for interiors. The beginning of the end or the end of the beginning. Lighting Research and Technology, 36(4), 283-294.

Boyce, P. R., Veitch, J. A., Newsham, G. R., Jones, C.
C., Heerwagen, J., Myer, M., \& Hunter, C. M. (2006). Occupant use of switching and dimming controls in offices. Lighting Research and Technology, 38(4), 358-378.

Brauer, W., Lozano-Ehlers, I., Greisle, A., Hube, G., Keiter, J., \& Rieck, A. (2003). Office 21-Push for the Future Better Performance in Innovative Working Environments. Cologne/Stuttgart: Fraunhofer.

Burgess-Limerick, R., Mon-Williams, M., \& Coppard, V. L. (2000). Visual display height. Human Factors, 42(1), 140-150.

Bush, T., \& Hubbard, R. (1999). An evaluation of postural motions, chair motions and contact in four office seats. Paper presented at the the Human Factors and Ergonomics Society 43rd Annual Meeting, Houston, Texas, pp. 589-593.

Chapanis, A. (1996). Human Factors in Systems Engineering. New York: J. Wiley.

de Looze, M. P., van Rhijn, J. W., Schoenmaker, N., van der Grinten, M. P., \& van Deursen, J. (2005). Productivity and discomfort in assembly work the effects of an ergonomic workplace adjustment at Philips DAP. In P. Vink (Ed.), Comfort and Design: Principles and Good Practice (pp. 129-136). Boca Raton: CRC Press.

Hedge, A., \& Sakr, W. (2005). Workplace effects on office productivity: a macroergonomic framework. In P. Carayon, M. Robertson, B. Kleiner \& P. L. T. Hoonakker (Eds.), Human Factors in Organizational Design and Management_-VIII (pp. 75-80). Santa Monica: IEA Press.

Hendrick, H. (2001). Good Ergonomics is Good Economics. Santa Monica: HFES press.

Horgen, G., Helland, M., Kvikstad, T. M., \& Aarås, A. (2007). Productivity Changes and State of Refraction Among Young versus Presbyopic VDUworkers at Different Background Luminance Levels. Paper presented at the 39th Annual Conference of the Nordic Ergonomic Society, Sweden.

Jainta, S., \& Jaschinski, W. (2002). Fixation disparity, binocular vergence accuracy for a visual display at different positions relative to the eyes. Human 
Factors, 44(3), 443-450.

Jaschinski, W., Heuer, H., \& Kylian, H. (1998). Preferred position of visual display relative to the eyes, a field study of visual strain and individual differences. Ergonomics, 41(7), 1034-1049.

Juslén, H., \& Tenner, A. (2005). Mechanisms involved in enhancing human performance by changing the lighting in the industrial workplace. International Journal of Industrial Ergonomics, 35(9), 843-855.

MacLeod, D. (2000). The Rules of Work: a Practical Engineering Guide to Ergonomics. New York: Taylor \& Francis.

Phesant, S. (2003). Bodyspace-Anthropometry, Ergonomics and the Design of Work (2 ed.). London: Taylor \& Francis.

Phillips, R. J. (1979). Why is lower case better? Some data from a search task. Applied Ergonomics, 10(4), 211-214.

Piccoli, B. (2003). A critical appraisal of current knowledge and future directions of ergophtalmology: consensus document of the ICOH Committee on "Work and Vision". Ergonomics, 46(4), 384-406.

Reinicke, S., Weisman, G., Stifter, A., \& Pope, M. H. (1986). Effects of seating posture on pressure distribution in office seating. Paper presented at the 19th Annual Meeting of the Human Factors Association of Canada, Richmond (Vancouver), British Columbia, pp. 11-13.

Robertson, M. M., Amick III, B. C., DeRango, K., Rooney, T., Bazzani, L., Harrist, R. H., \& Moore, A. (2009). The effects of an office ergonomics training and chair intervention on worker knowledge, behavior and musculoskeletal risk. Applied
Ergonomics, 40(1), 124-135.

Rosecrance, J., Dpuphrate, D., \& Cross, S. (2005). Integration of participatory ergonomics and lean manufacturing: a model and case study. In P. Carayon, M. Robertson, B. Kleiner \& P. L. T. Hoonakker (Eds.), Human Factors in Organizational Design and Management-VIII (pp. 437-442). Santa Monica: IEA Press.

Rulebook on preventive measures for safe and healthy work, when using the work equipment, "Official Gazette of the Republic of Serbia" nr. 106/09.

Sadeghi Naeini, H., \& Heidaripour, M. K. (2011). Kansei Engineering and Ergonomic Design of Products. International Journal of Occupational Hygiene, 3(2), 81-84.

Sommerich, C., Joines, S., \& Psihogios, J. (2001). Effects of computer monitor viewing angle and related factors on strain, performance, and preference outcomes. Human Factors, 43(1), 39-55.

Taptagaporn, S., Sotoyama, M., Saito, S., Suzuki, T., \& Saito, S. (1995). Visual comfort in VDT workstation design. Journal of Human Ergology, 24(1), 84-88.

Tayyari, F., \& Smith, J. L. (1997). Occupational Ergonomics; Principles and Applications. London:Chapman \& Hall.

Vink, P., de Jong, A., \& Koningsveld, E. (2005). Making money with participatory ergonomics. In P. Carayon, M. Robertson, B. Kleiner \& P. L. T. Hoonakker (Eds.), Human Factors in Organizational Design and Management-VIII (pp. 443-448). Santa Monica: IEA Press.

Vink, P., \& Kompier, M. A. J. (1997). Improving office work: a participatory ergonomic experiment in a naturalistic setting. Ergonomics, 40(4), 435-449. 